\title{
A REVIEW OF NANOFLUID ADOPTION IN POLYMER ELECTROLYTE MEMBRANE (PEM) FUEL CELLS AS AN ALTERNATIVE COOLANT
}

\author{
Irnie Zakaria ${ }^{1 *}$, Z. Michael ${ }^{1}$, W.A.N.W. Mohamed ${ }^{1}$, A.M.I. Mamat ${ }^{1}$, W.H. Azmi ${ }^{2}$, \\ R. Mamat $^{2}$ and R. Saidur ${ }^{3}$
}

Alternative Energy Research Centre

Faculty of Mechanical Engineering, Universiti Teknologi Mara

40450 Shah Alam, Selangor, Malaysia

*Email: irnieazlin@googlemail.com

Phone:+603-55442000; Fax: +603-55443102

${ }^{2}$ Faculty of Mechanical Engineering

Universiti Malaysia Pahang, 26600 Pekan, Pahang, Malaysia

${ }^{3}$ Center of Research Excellence in Renewable Energy

King Fahd University of Petroleum and Minerals

31261 Dahran Saudi Arabia

\begin{abstract}
Continuous need for the optimum conversion efficiency of polymer electrolyte membrane fuel cell (PEMFC) operation has triggered varieties of advancements, namely in the thermal management engineering scope. Excellent heat dissipation is correlated with higher performance of a fuel cell, thus increasing its conversion efficiency. This study reveals the potential advancement in thermal engineering of a fuel cell cooling system with respect to nanofluid technology. Nanofluids are seen as a potential evolution of nanotechnology hybridization with the fuel cell serving as a cooling medium. The available literature on the thermophysical properties of potential nanofluids, especially on the electrical conductivity property, has been discussed. The lack of electrical conductivity data for various nanofluids in open literature was another challenge in the application of nanofluids in fuel cells. Unlike in any other thermal management system, a nanofluid in a fuel cell is dealt with using a thermoelectrically active environment. The main challenge in nanofluid adoption in fuel cells was the formulation of a suitable nanofluid coolant with heat transfer enhancement, as compared to its base fluid, but still complying with the strict limits of electrical conductivity as low as $2 \mu \mathrm{S} / \mathrm{cm}$ and several other restrictions discussed by the researchers. It is concluded that a nanofluid in PEMFC is advantageous in terms of both heat transfer and simplification of the cooling system through radiator size reduction and potential elimination of the deionizer as compared to the current PEMFC cooling system. However, there are challenges that need to be well addressed, especially in the electrical conductivity requirement.
\end{abstract}

Keywords: Thermal management; PEM fuel cell; Nanofluid.

\section{INTRODUCTION}

A fuel cell is an energy conversion device using hydrogen-based fuel with oxygen through a polarized electrochemical reaction. It is seen as a potential power source 
substituting the internal combustion engine in the automotive industry due to its excellent conversion efficiency and zero pollution emissions [1]. However, there is a critical need to enhance the heat transfer in the fuel cell since there is a significant amount of heat generated which will eventually cause the polymer electrolyte membrane fuel cell (PEMFC) component to overheat, especially the membrane [1-3]. Several cooling systems, namely heat spreaders, air cooling, liquid cooling and phase change cooling, were reviewed by Zhang and Khandlikar [4]. Among these cooling techniques, liquid cooled was the most suitable for automotive applications, especially for a PEMFC stack with higher power than $5 \mathrm{~kW}$ [5]. There have been initiatives from researchers to improve the current conventional methods for liquid cooled fuel cells, namely cooling channel design optimization, flow field optimization and cooling system enhancement via $\mathrm{CO}_{2}$ air conditioning as supplementary stack cooling [4, 6, 7]. However, there is still room for improvement in areas other than geometrical optimization, either with regard to the fuel cell stack or heat exchanger, in order to fulfill the criteria of compact, simplified, and lighter weight fuel cell systems with superior power density compared to the conventional liquid cooling strategy.

Nanofluid studies have become a phenomenon in thermal engineering due to their superior thermal conductivity as compared to base fluids. Nanofluids are prepared by dispersing ultra-fine nanometer sized (less than $100 \mathrm{~nm}$ ) metallic or non-metallic materials into a base fluid [8-12]. A wide range of feasible applications of nanofluids in heat transfer has been summarized by Saidur et al. [13] covering all ranges of cooling application except for electrically active environmental devices such as fuel cells. This paper reviews the possibility of nanofluid adoption as an alternative coolant in PEMFC cooling systems. Section 1 reviews the concept of PEMFC while Section 2 describes the fundamental thermal management in PEMFC and the current approach to liquid cooled PEMFCs. All possible advantages and challenges are reviewed in Sections 3 and 4 consecutively. Lastly the conclusions and possible further work are given in Section 5.

\section{OVERVIEW OF FUEL CELL}

The PEMFC is best suited for many applications due to its high power density and excellent dynamics characteristics as compared to other types of fuel cells [14]. The PEMFC converts hydrogen energy directly into electrical energy via electrochemical reactions with oxygen. Electrochemical reactions occur at the catalyst layer surface which is interfaced between the gas diffusion layer and the membrane, as illustrated in Figure 1. Hydrogen is diffused through the gas diffusion layer and is catalytically split into its constituents of protons and electrons in the catalyst layer. The sandwiched polymer membrane allows only protons to travel through by its mechanism, while free electrons travel through the external circuitry. This will eventually be the net result (electric current) of this electrochemical reaction. At the cathode side, the hydrogen protons and electrons will meet and react with oxygen molecules, thus producing water as a by-product of this electrochemical reaction. Electrochemical reactions happen simultaneously in both the anode and cathode and are represented as follows

At the anode side

$$
H_{2} \rightarrow 2 H^{+}+2 e^{-}
$$


At the cathode side

$$
\frac{1}{2} \mathrm{O}_{2}+2 \mathrm{H}^{+}+2 e^{-} \rightarrow \mathrm{H}_{2} \mathrm{O}
$$

Thus giving an overall reaction of

$$
2 \mathrm{H}_{2} \mathrm{O}+\mathrm{O}_{2} \rightarrow 2 \mathrm{H}_{2} \mathrm{O}
$$

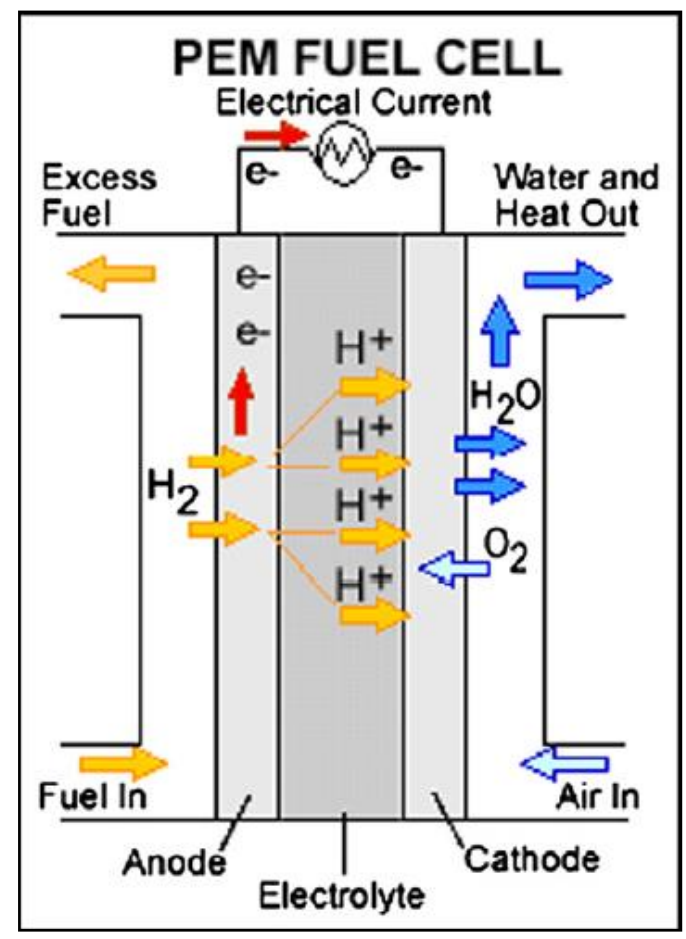

Figure 1. Schematic of a proton exchange fuel cell [15].

The formation of water and the internal resistance of the electrical circuit generate heat as another by-product and the concentration is normally higher at the cathode side contributing to the formation of water. This phenomenon requires good thermal management in order to avoid the membrane overheating as this can lead to stack performance deterioration. There is a high concentration of free electrons in the bipolar plate adjacent to the cooling plate of the PEMFC so as to allow rapid heat conduction to the cooling channels. This arrangement, however, enables the electrons to leak to the coolant passage, termed shunt current, resulting in voltage loss in the fuel cell stack. Furthermore, the shunt current is also a potential threat to corrosion of the separator plate in a fuel cell and also hazardous to the operator [16].

\section{THERMAL MANAGEMENT OF A PEMFC}

Thermal power dissipated in the fuel cell is estimated through the thermodynamic energy balance in the cell [1]. 


$$
P_{\text {thermal }}=P_{\Delta H}-P_{\text {elect }}
$$

where $P_{\text {thermal }}$ is the thermal power generated by the fuel cell, $P_{\Delta H}$ is the theoretical power produced by the electrochemical reactions of the gases and $P_{\text {elect }}$ is the electrical power produced by the fuel cell. Conversion efficiency for a fuel cell stack is described by

$$
\eta_{\text {conv }}=\frac{P_{\text {elect }}}{P_{\Delta H}}
$$

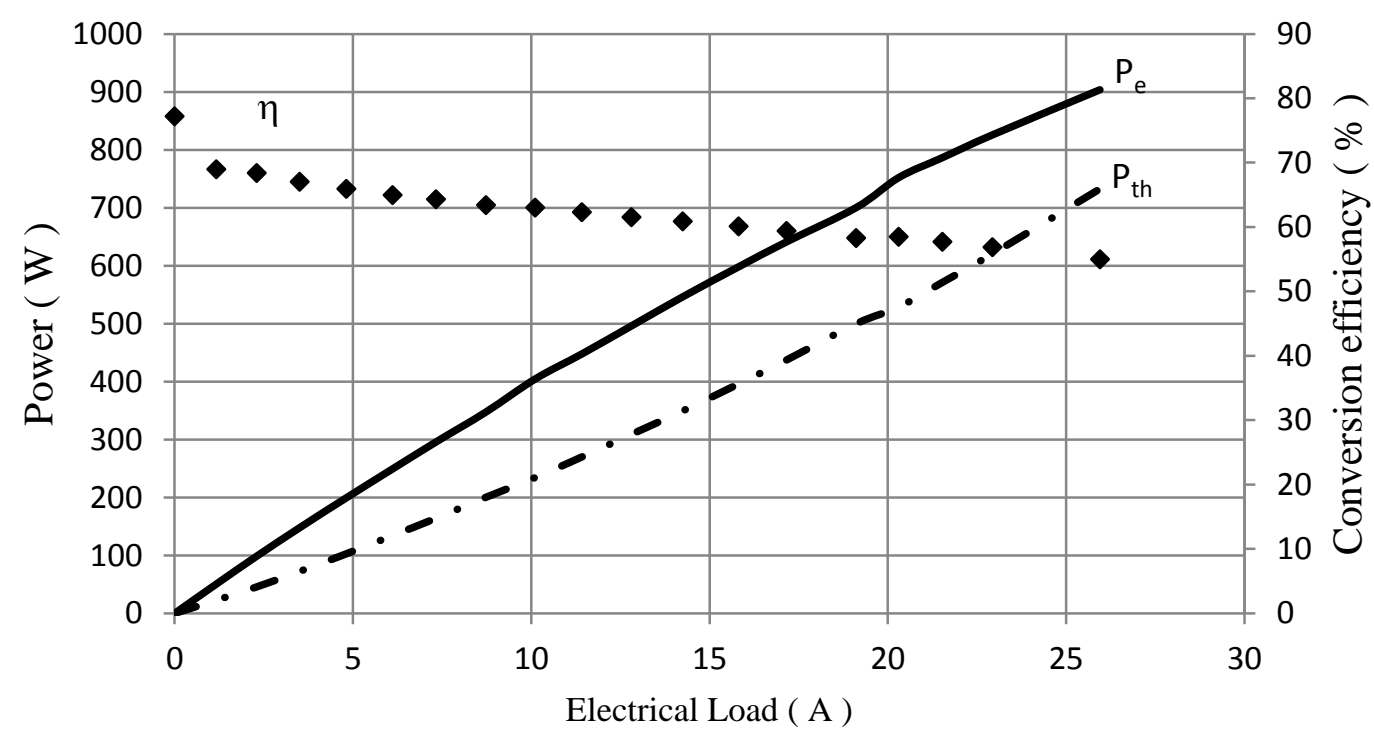

Figure 2. Electrical and thermal power relationship based on the conversion efficiency of a H1000XP- Horizon [17].

Optimal thermal management acquisition is needed in PEMFC in order to increase the efficiency as electrical power is directly accompanied by almost equivalent thermal power, depending on the conversion efficiency, as illustrated in Figure 2. Heat generated in the fuel cell is governed by

$$
Q_{\text {gen }}=\left(1.254-V_{\text {cell }}\right) . I \cdot n_{\text {cell }}
$$

where it is assumed that all product water leaves the stack as vapor at $25^{\circ} \mathrm{C}$. Generated heat from the fuel cell is dissipated in several ways, such as conducted through the gas diffusion layer and the bipolar plates, and also to the reactant gas and surroundings through convection and radiation. However, the prime bulk of heat passes to the cooling medium through convection.

Heat transfer by cooling fluid is expressed by Newton's law of cooling [18]

$$
Q=h A \Delta T
$$

where $\mathrm{Q}$ denotes heat flow, $h$ is the heat transfer coefficient, $A$ is the effective heat transfer area and $\Delta T$ is the temperature difference between the coolant out and coolant 
in fuel cell stack. A greater value of $\Delta T$ may help to increase the heat dissipation but it is debatable since lowering the temperature of the coolant will eventually lower the kinetic energy potential of the hydrogen molecules and may also cause flooding due to lower water saturation pressure at lower temperatures [4].

Several challenges are associated with thermal efficiency due to its low operating temperature which is in the range of $60{ }^{\circ} \mathrm{C}$ to $80{ }^{\circ} \mathrm{C}$. A higher temperature than this may lead to membrane overheating or excessive drying, thus affecting performance. A lower temperature is also unfavorable as it can lead to a flooding issue due to the lower water saturation pressure at a lower temperature and also a reduction in kinetic energy which is also unfavorable in terms of reactant reactions $[4,19]$.
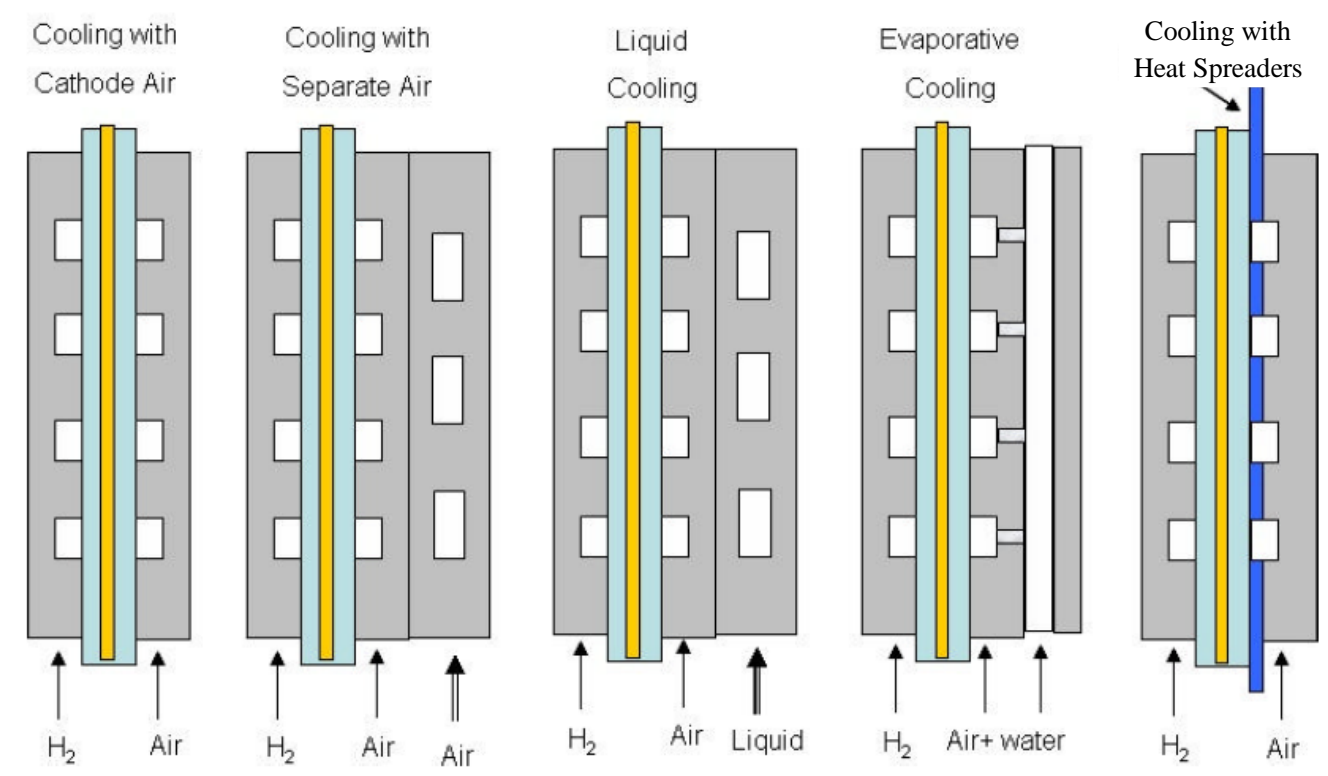

Figure 3. PEM fuel cell cooling strategies [20].

Selection based on the need of specific cooling strategies depends on the size and application of the stack [20]. These cooling strategies were critically reviewed by Zhang [4] in order to promote more effective cooling strategies through reporting the advantages and challenges associated with each specific cooling strategy. Cooling strategies in general can be classified as cooling with cathode air, cooling with separate air, liquid cooling, evaporative cooling and cooling with heat spreaders, also known as edge cooling. The currently used cooling strategies are simplified in Figure 3. Apart from increasing $\Delta T$, maximizing the effective heat transfer area $A$ is seen as a common strategy to improve heat transfer performance. However, employing such a strategy in the fuel cell with mini channel cooling is not an option due to the space constraint. This is also true in most of the applications, for instance, microprocessor and micro electro mechanical systems (MEMS) [13]. Alternatively, the heat transfer coefficient $h$ can be further enhanced either through more efficient heat transfer methods, which employ forced convection over free convection, or through improving the transport properties of the heat transfer material via the addition of nanoparticles to the coolant, termed nanocoolant or sometimes nanofluid, to the cooling liquid. 


\section{NANOFLUID POTENTIAL IN LIQUID COOLED PEMFC}

Deionized (DI) water is currently used as the coolant in a PEMFC due to its excellent electrical resistivity, as high as $18 \mathrm{M} \Omega . \mathrm{cm}$. DI water also has good thermal conductivity, greater than $0.6 \mathrm{~W} / \mathrm{m} . \mathrm{K}$, higher than $3 \mathrm{~kJ} / \mathrm{kg} . \mathrm{K}$ specific heat capacity while maintaining a relatively low viscosity of less than $1 \mathrm{cP}$ at $80{ }^{\circ} \mathrm{C}$ and $6 \mathrm{cP}$ at $0{ }^{\circ} \mathrm{C}$. However, its electrical resistivity tends to degrade over time as water easily picks up ions from metals and other sources. Applications in cold countries are also limited due to the freezing point of $0{ }^{\circ} \mathrm{C}$ [21]. The application of nanofluids in fuel cells is a new area of research that started in 2004 with a small business innovation research (SBIR) grant from the United States of America Department of Energy (DOE) [22]. Some of the initial work on nanofluids in PEMFC was carried out by Mohapatra with the formulation of a mixture of water and glycol coolant with nanoparticles, non-ionic corrosion inhibitor and polymeric ion suppressant with the target of improving all the thermophysical properties of deionized water while retaining the electrical conductivity preferably below $2 \mu \mathrm{S} / \mathrm{cm}$ [23]. Mohapatra addressed that the base fluid is responsible for the freezing point, flash points and compatibility with other materials used in fuel cell cooling systems while the additive package helps maintain low electrical conductivity. The criteria for a PEMFC coolant, covering all important themophysical property requirements were tabulated by Mohapatra et al. and are shown in Table 1 .

Table 1. Criteria for PEM fuel cell coolant [24].

\begin{tabular}{|c|c|c|}
\hline Criteria & Description & Specification \\
\hline $\begin{array}{l}\text { Electrical } \\
\text { Conductivity }\end{array}$ & $\begin{array}{l}\text { Conductive coolant will reduce the } \\
\text { performance of the fuel cell as well } \\
\text { as increase the shock hazard for } \\
\text { personnel in contact }\end{array}$ & $<2.0 \mu \mathrm{S} / \mathrm{cm}$ \\
\hline Boiling Point & $\begin{array}{l}\text { Boiling point should be more than } \\
\text { the highest bulk temperature of the } \\
\text { coolant }\end{array}$ & $>90^{\circ} \mathrm{C}$ \\
\hline Freezing Point & $\begin{array}{l}\text { Must be freeze tolerant under } \\
\text { extreme cold conditions }\end{array}$ & $<-40^{\circ} \mathrm{C}$ \\
\hline Thermal Conductivity & Higher is better for heat transfer & $>0.4 \mathrm{~W} / \mathrm{m} . \mathrm{K}$ \\
\hline Viscosity & $\begin{array}{l}\text { Lower is better for heat transfer and } \\
\text { pumping power }\end{array}$ & $<1.0 \mathrm{cP}$ at $80^{\circ} \mathrm{C}$ \\
\hline Specific Heat & Higher is better for heat transfer & $>3 \mathrm{~kJ} / \mathrm{kg} \cdot \mathrm{K}$ \\
\hline Durability & $\begin{array}{l}\text { More durable coolant will reduce the } \\
\text { operating cost }\end{array}$ & $\begin{array}{l}>5000 \text { hrs of operation } \\
\text { ( } 2 \text { years of lifetime })\end{array}$ \\
\hline $\begin{array}{l}\text { Material } \\
\text { Compatibility }\end{array}$ & $\begin{array}{l}\text { Coolant must be compatible with } \\
\text { stainless steel, sillicone, EPDM, } \\
\text { Viton and other fuel cell component } \\
\text { materials }\end{array}$ & - \\
\hline Toxicity & $\begin{array}{l}\text { Should be classified as non-toxic for } \\
\text { transportation }\end{array}$ & $\begin{array}{l}\text { Similar or less toxic } \\
\text { than ethylene glycol } \\
\text { (EG) }\end{array}$ \\
\hline Flammabality & $\begin{array}{l}\text { Should be classified as non- } \\
\text { flammable }\end{array}$ & Flash point $>93.3^{\circ} \mathrm{C}$ \\
\hline
\end{tabular}




\section{ADVANTAGES OF NANOFLUIDS IN PEMFC}

\section{Heat Transfer Enhancement}

Dispersion of nanoparticles, either metallic or non-metallic, in the base fluid will tremendously increase the convective heat transfer performance of the coolant. The main reason for this enhancement is due to the higher magnitudes of thermal conductivity of nanofluids as compared to conventional fluids. The thermal conductivity enhancement of several nanofluids is tabulated in Table 2. Nano sized particles also play a role in enhancement as they introduce larger surface areas for thermal interactions [13]. Brownian motion or intensified interaction and collision among the particles also improved, eventually improving the heat transfer as well [25]

Table 2. Thermal conductivity enhancement of nanofluids.

\begin{tabular}{|c|c|c|c|c|c|c|c|}
\hline & $\begin{array}{l}\text { Nano } \\
\text { particle }\end{array}$ & Base fluid & $\begin{array}{l}\text { Nanoparticle } \\
\text { size }(\mathrm{nm})\end{array}$ & $\begin{array}{l}\text { Vol } \\
\text { fraction } \\
(\%)\end{array}$ & Author & $\begin{array}{c}\text { Enhancement } \\
(\%)\end{array}$ & Ref \\
\hline \multirow{2}{*}{$\begin{array}{l}\text { Metallic } \\
\text { nnf }\end{array}$} & $\mathrm{Cu}$ & EG & 10 & 0.3 & $\begin{array}{l}\text { Choi et } \\
\text { al. }\end{array}$ & 40 & [8] \\
\hline & $\mathrm{Cu}$ & EG & $<10$ & 0.3 & $\begin{array}{l}\text { Eastman } \\
\text { et al. }\end{array}$ & 40 & [26] \\
\hline \multirow{11}{*}{$\begin{array}{l}\text { Non- } \\
\text { metallic }\end{array}$} & $\mathrm{Al}$ & EG & 80 & 5 & & 45 & \\
\hline & $\mathrm{TiO}_{2}$ & EG & 15 & 5 & $\begin{array}{l}\text { Murshed } \\
\text { et al. }\end{array}$ & 18 & [27] \\
\hline & $\mathrm{Al}_{2} \mathrm{O}_{3}$ & & 38 & 5 & & 18 & \\
\hline & $\mathrm{CuO}$ & Water:EG & 23.6 & 4 & Lee et al. & & [28] \\
\hline & $\mathrm{Al}_{2} \mathrm{O}_{3}$ & Water:EG & 28 & 5 & $\begin{array}{l}\text { Wang et } \\
\text { al. }\end{array}$ & 26 & [29] \\
\hline & $\mathrm{Al}_{2} \mathrm{O}_{3}$ & Water:EG & 60.4 & 5 & Xie et al. & 30 & [30] \\
\hline & $\mathrm{Al}_{2} \mathrm{O}_{3}$ & EG & 29 & 4 & & 18 & [31] \\
\hline & $\mathrm{TiO}_{2}$ & EG & 40 & 5 & $\begin{array}{l}\text { Wang et } \\
\text { al. }\end{array}$ & 13 & \\
\hline & $\mathrm{CuO}$ & EG & 12 & 1 & $\begin{array}{l}\text { Kwak } \\
\text { and Kim }\end{array}$ & 6 & [32] \\
\hline & $\mathrm{Al}_{2} \mathrm{O}_{3}$ & $\begin{array}{c}\text { EG:water at } \\
20 \text { to } 60 \text { deg } \\
\text { C }\end{array}$ & $\begin{array}{l}(20: 80) 1.5 \\
(40: 60) \\
(60: 40)\end{array}$ & 1.5 & $\begin{array}{l}\text { Sundar } \\
\text { et al. }\end{array}$ & $\begin{array}{r}\text { @ } 60 \mathrm{deg} \\
32.26 \%\end{array}$ & [33] \\
\hline & $\mathrm{CuO}$ & EG & 35 & 4 & $\begin{array}{l}\text { Eastman } \\
\text { et al. }\end{array}$ & 22 & [26] \\
\hline
\end{tabular}

\section{PEMFC Cooling System Simplification}

Dynalene, a coolant manufacturer in the United States of America, launched Dynalene fuel cell (FC) in 2013 which is specially designed to maintain less than $1 \mu \mathrm{S} / \mathrm{cm}$ for at least 2 years while providing excellent heat transfer properties similar to a water based 
coolant [34], even after 2 years. Dynalene FC is designed to suppress the formation of ions by two mechanisms: utilizing highly charged nanoparticles which scavenge and bond to free ions resulting in low electrical conductivity of the coolant and also through the use of a non-ionic corrosion inhibitor that reduces the corrosion rate of the components in an FC cooling system as presented in Figure 4. The capability of selfdeionizing the coolant has added advantages to the system simplification as there is an opportunity for deionizer deletion. Deionization is needed in a conventional coolant as water becomes conductive when coming into contact with material in the closed loop and becomes contaminated with lots of ions. Ions are produced from the contamination of the bipolar plate (Dill \& WalWorth, 2005) and the oxidation of glycol [4] as it degrades. Besides the deionizer, adding antioxidant to the coolant [35] and through kerosene hydrocarbon coolant and the addition of carboxylic acid to the coolant consecutively [36] [16] the free ions issue which will eventually make the coolant conductive can also be reduced. A smaller pump to circulate the coolant through the loop is also possible due to the deletion of the deionizer. This will reduce the parasitic loss associated with the pump. This system simplification, illustrated in Figure 3, will consequently improve the overall efficiency [24]. Figure 5 shows comparison between conventional and nanofluid PEMFC cooling systems.

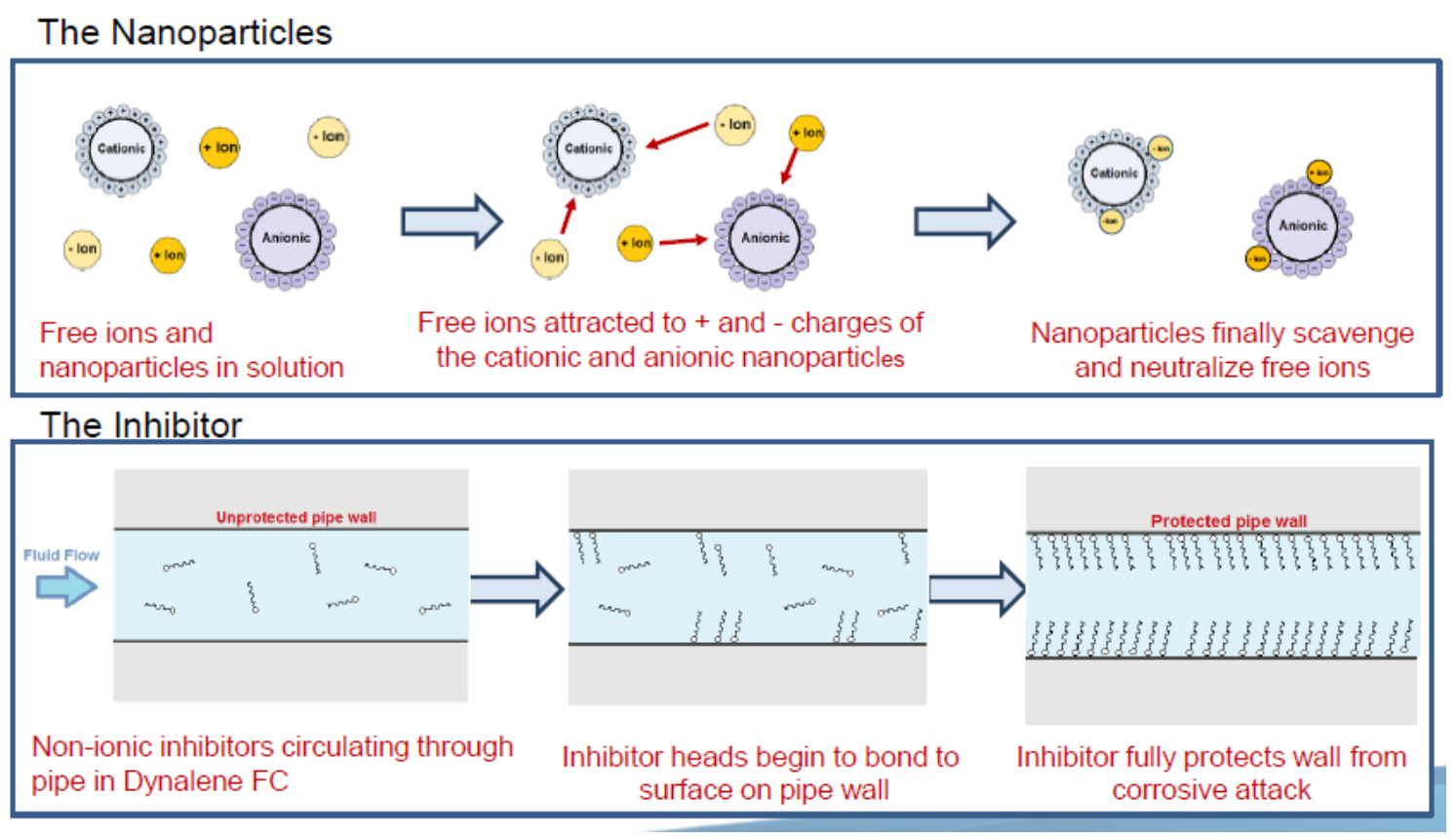

Figure 4. Mechanism used by Mohapatra to reduce electrical conductivity [22].

\section{CHALLENGES OF NANOFLUIDS IN PEMFC}

\section{Electrical Conductivity}

The most critical aspect of the nanofluid in the PEMFC is the low electrical conductivity requirement which is as low as 1.5 to $2 \mu \mathrm{S} / \mathrm{cm}[24]$ and $5 \mu \mathrm{S} / \mathrm{cm}$ at $20{ }^{\circ} \mathrm{C}$ [37] and needs to be maintained over time. Electrical conductivity of a nanofluid is correlated to the ability of the charged ions in the nanofluid mixture to carry electrons, also called charges, whenever an electric potential is applied [38]. This is possible due to the formation of an electrical double layer (EDL) around the surface of the dispersed 
nanoparticles. The whole structural movement towards the oppositely charged electrode is measured as the electrical conductivity of a nanofluid.

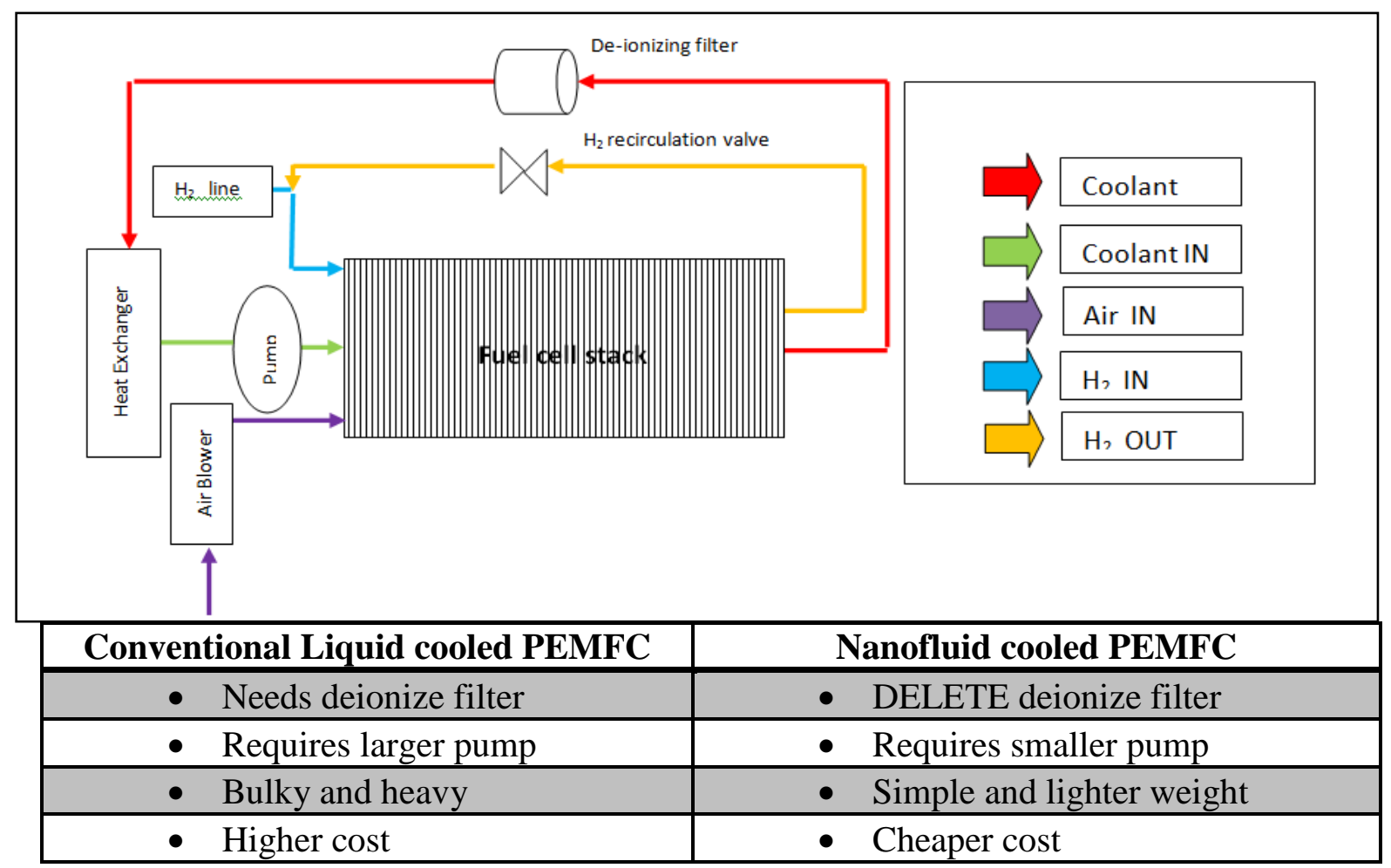

Figure 5. Comparison between conventional and nanofluid PEMFC cooling systems.

Electrical conductivity is the least investigated of all the thermophysical properties of nanofluids. Literature sources on this property are very scarce, perhaps due to the lack of nanofluid applications in electrically active thermal devices such as PEMFCs. The lack of studies on electrical conductivity can be seen from the tabulated thermophysical property study in Table 3. PEMFC cooling system applications would require judgment as to whether or not the electrical conductivity properties are feasible for the system. The electrical conductivity requirement, which is as low as 1.5 to $2 \mu \mathrm{S} / \mathrm{cm}$ [39] and $5 \mu \mathrm{S} / \mathrm{cm}$ at $20{ }^{\circ} \mathrm{C}$ [37], needs to be maintained over time. A few researchers have investigated the effect of electrical conductivity on various types of nanofluids [40-51]. Wong and Kurma [40] studied the effect of volume concentration on the electrical conductivity of $\mathrm{Al}_{2} \mathrm{O}_{3}$ nanofluid. They observed that electrical conductivity is highly increased with a small volume concentration. The increment of electrical conductivity is up to $3457.1 \%$ for a volume concentration of $1.44 \%$. The highest value of electrical conductivity was $314 \mu \mathrm{S} / \mathrm{cm}$ and measured at $8.47 \%$ of volume concentration. Further investigation of the electrical conductivity of $\mathrm{Al}_{2} \mathrm{O}_{3}$ nanofluid was carried out by Ganguly et al. [41] and Minea and Luciu [49]. Ganguly et al. [41] investigated $\mathrm{Al}_{2} \mathrm{O}_{3}$ dispersed in deionized water. They measured the effective electrical conductivity as a function of the volume fraction (0.005 to 0.03$)$ and temperature $\left(25\right.$ to $45^{\circ} \mathrm{C}$ ). They concluded that the volume fraction effect is more prominent than that of temperature. Minea and Luciu [49] measured the electrical conductivity of $\mathrm{Al}_{2} \mathrm{O}_{3}$ dispersed in water and observed that the electrical conductivity tremendously increased by $390.11 \%$ at $60{ }^{\circ} \mathrm{C}$ for $4 \%$ volume fraction. However, they 
mentioned that the conventional models, such as Maxwell's [52] and Bruggeman's [53] do not correlate to the findings. This observation is also supported by Sundar et al. [38].

Table 3. Review of the thermophysical properties of nanofluids.

\begin{tabular}{|c|c|c|c|c|c|c|}
\hline \multirow[t]{2}{*}{ Author } & \multirow{2}{*}{$\begin{array}{l}\text { Nano } \\
\text { particle }\end{array}$} & \multirow[t]{2}{*}{ Base fluid } & \multirow[t]{2}{*}{ Mode * } & \multicolumn{3}{|c|}{ Property studied } \\
\hline & & & & $* \mathrm{TC}$ & Viscosity & $* \mathrm{EC}$ \\
\hline [54] & $\mathrm{Al}_{2} \mathrm{O}_{3}$ & $\begin{array}{c}\text { Water, } \\
\text { polyalphaol } \\
\text { efin }\end{array}$ & $\mathrm{E}$ & $\mathrm{X}$ & $\mathrm{X}$ & \\
\hline [51] & $\begin{array}{c}\mathrm{Cu} \\
\mathrm{Al}_{2} \mathrm{O}_{3}, \mathrm{CuO}\end{array}$ & Water, EG & $\mathrm{E}$ & & & $X$ \\
\hline$[55]$ & $\mathrm{Al}_{2} \mathrm{O}_{3}$ & Water & $\mathrm{E}$ & $\mathrm{X}$ & $\mathrm{X}$ & $\mathrm{X}$ \\
\hline$[50]$ & Graphene & $\begin{array}{c}\text { EG : Water } \\
(70: 30)\end{array}$ & $\mathrm{E}$ & $X$ & $\mathrm{X}$ & $X$ \\
\hline [41] & $\mathrm{Al}_{2} \mathrm{O}_{3}$ & Water & $\mathrm{E}$ & $X$ & & $X$ \\
\hline$[56]$ & Graphene & Water, EG & $\mathrm{E}$ & $X$ & & $X$ \\
\hline [27] & $\begin{array}{c}\mathrm{TiO}_{2}, \mathrm{Al} \\
\mathrm{Al}_{2} \mathrm{O}_{3}\end{array}$ & $\begin{array}{c}\text { DI } \\
\text { Water,Wate } \\
\text { r EG, } \\
\text { Engine Oil }\end{array}$ & $\mathrm{E} \& \mathrm{~T}$ & $X$ & $\mathrm{X}$ & \\
\hline [57] & $\mathrm{TiO}_{2}$ & Water & $\mathrm{E}$ & $X$ & $X$ & \\
\hline$[58]$ & $\begin{array}{c}\mathrm{Al}_{2} \mathrm{O}_{3}, \mathrm{CuO} \\
\& \mathrm{ZnO}\end{array}$ & $\begin{array}{c}\text { EG:Water; } \\
\text { 60:40 }\end{array}$ & $\mathrm{T} \& \mathrm{E}$ & $\mathrm{X}$ & & \\
\hline [59] & $\mathrm{AgNO}_{3}$ & EG & $\mathrm{T} \& \mathrm{E}$ & $X$ & & \\
\hline$[60]$ & $\mathrm{Al}_{2} \mathrm{O}_{3}$ & Water & $\mathrm{T} \& \mathrm{E}$ & $X$ & $\mathrm{X}$ & \\
\hline [61] & $\mathrm{SiC}$ & $\begin{array}{l}\text { Deionized } \\
\text { water } \\
\text { (DIW) }\end{array}$ & $\mathrm{E}$ & $\mathrm{X}$ & $\mathrm{X}$ & \\
\hline$[62]$ & $\mathrm{TiO}_{2}, \mathrm{Al}_{2} \mathrm{O}_{3}$ & $\begin{array}{c}\text { Water \& } \\
80: 20 \text { Water } \\
\text { : EG }\end{array}$ & $\mathrm{T} \& \mathrm{E}$ & $\mathrm{X}$ & & \\
\hline [13] & Various & Various & $\mathrm{R}$ & $X$ & & \\
\hline$[63]$ & Various & Various & $\mathrm{R}$ & $X$ & & \\
\hline [64] & Various & Various & $\mathrm{R}$ & & $X$ & \\
\hline
\end{tabular}

* E-Experimental, $\mathrm{T}-$ Theoretical and $\mathrm{N}$ - Numerical

* TC - thermal conductivity *EC - electrical conductivity

Sarojini et al. [51] experimented with nanoparticles of $\mathrm{Al}_{2} \mathrm{O}_{3}, \mathrm{CuO}$ and $\mathrm{Cu}$ in distilled water and EG. Their findings show that electrical conductivity increases as the volume concentration increases. The increment in distilled water is significantly higher than the nanofluid in EG due to the higher value of the dielectric constant of 80 in distilled water as compared to the value of 38 in EG. They also investigated the influence of various physico-chemical factors on the electrical conductivities of both 
metal and ceramic nanoparticles. These factors include the effect of a nanoparticle and base fluid combination, stabilization of the nanofluid, surfactant addition, the particle size and also the temperature effect. They mentioned that the stability of nanofluids strongly depends on the surface charge of the nanoparticle, which is related to the value of the thermal conductivity. More studies are available for different types of nanofluids, such as carbon by Teng et al. [43], $\mathrm{SiO}_{2}$ and $\mathrm{ZnO}$ by Konakachi et al. [46], $\mathrm{TiO}_{2}$ by Sikdar [44], ZnO insulated with oil nanofluid by Shen et al. [48], and nanodiamondnickel (ND-Ni) nanocomposite by Sundar et al. [38]. The effect of temperature on the electrical conductivity of a low concentration of $\mathrm{Al}_{2} \mathrm{O}_{3}$ nanofluid in a water:EG mixture has also been investigated by Bin Razali et al. [65]. Zakaria et al. [66] established a thermo-electrical conductivity (TEC) ratio for $\mathrm{Al}_{2} \mathrm{O}_{3}$ nanofluid in a water:EG mixture for a (PEM) fuel cell considering both thermal and electrical enhancement. According to the findings, $\mathrm{Al}_{2} \mathrm{O}_{3}$ in a water:EG mixture with more than $50 \% \mathrm{EG}$ content has a better TEC value over $\mathrm{Al}_{2} \mathrm{O}_{3}$ in water or in a water:EG mixture with an EG content lower than $50 \%$. The finding was later proved through experimental analysis of a $400 \mathrm{~W}$ PEMFC. Nanofluid adoption in PEMFC improved the thermal performance but the performance effect cannot be seen due to the nanofluid and the lower wattage PEMFC tested [67].

\section{Higher pumping power in mini channel geometry}

Mini channels have been adopted in PEMFC cooling plate designs as they allow a more compact stack size and improved heat transfer rates that lead to a lower maximum cell temperature [68-70]. Adoption in the PEMFC stack would require the coolant to be forced through a narrow passage in the mini channel [71]. Nanofluids in mini channels have been experimentally investigated mostly for electronic heat sink and automotive heat exchangers [68, 72-74]. Nanofluid cooling effects at different nanoparticle fractions to variations in heat sink channel designs, operation and materials are normally reported. Naphon and Nakharintr [73] studied $\mathrm{TiO}_{2}$ in deionized water nanofluid heat transfer characteristics by varying three different channel heights. Sohel et al. [71] studied the effect of different flow rates on the thermal performance of $\mathrm{Al}_{2} \mathrm{O}_{3}$ in water at volume fractions ranging from 0.1 to $0.25 \%$. Both studies reported enhancements, of $42.3 \%$ and $11 \%$ of maximum convective heat transfer, respectively, compared to the base fluids. However, all the heat transfer enhancement comes with a demerit of higher pumping power. This is due to the increase in density and viscosity of the nanofluid as compared to the base fluid. Sedimentation build up in the mini channel also contributes to a higher pumping power requirement as compared to a conventional coolant.

Viscosity plays a vital role in determining whether a specific nanofluid gives a better thermal performance than its base fluid through a ratio of enhancement in viscosity over thermal conductivity, $\left(\mathrm{C}_{\mu} / \mathrm{C}_{\mathrm{k}}\right)$. Prasher [75] found that for the laminar range, the enhancement of viscosity has to be lower than 4 compared to thermal conductivity while Garg [76] limited the enhancement to 5 in turbulent flow. If the ratio goes beyond this limit, then the effectiveness of the nanofluid application in any specific case is arguable. Azmi et al. [77] introduced the advantage ratio to measure the feasibility of nanofluid adoption taking into account both heat transfer and pressure drop enhancement. 


\section{Compatibility with Other Components in PEMFC Cooling System}

Apart from the thermophysical characteristics, the fuel cell coolant needs to be compatible with the fuel cell component materials, namely stainless steel, sillicone, EPDM,Viton and others [24].

\section{CONCLUSIONS}

The potential and challenges of using nanofluids in PEMFCs is reviewed. Nanofluids offer great potential as a cooling medium due to their superior thermophysical properties, especially in thermal conductivity and convective heat transfer. However, the electrical conductivity thermophysical characteristics need to be further investigated in order to enable adoption in fuel cells. Challenges to the adoption are mainly in connection with the electrical conductivity properties and the pumping power increment in the mini channel. However, this pumping power increment needs to be further studied as a whole system parasitic loss, since nanofluids also have the potential to reduce the overall system pumping requirements through deletion of the deionizer fuel cell. The ratio of heat transfer enhancement to the additional pumping power requirement needs to be established in order to see the advantages of nanofluids for both the heat transfer and friction factor aspects in an active electrical heat transfer environment such as a fuel cell.

\section{ACKNOWLEDGEMENTS}

The author would like to acknowledge Ministry of Education (MOE) for granting a RAGS fund of 600-RMI/RAGS 5/3 (51/2013) from Research Management Institute (RMI) of Universiti Teknologi MARA for funding this research.

\section{REFERENCES}

[1] Barbir F. PEM Fuel Cells : Theory and Practice2005.

[2] Faghi A, Guo Z. Challenges and opportunities of thermal management issues related to fuel cell technology and modeling. International Journal of Heat and Mass Transfer. 2005;48:3891-920.

[3] Larminie J, dicks A. Fuel cell systems explained: John wiley and sons ltd.; 2003.

[4] Zhang G, Kandlikar SG. A critical review of cooling techniques in proton exchange membrane fuel cell stacks. international journal of hydrogen energy. 2012;37:2412-29.

[5] Curtin S, Gangi J. 2013 Fuel cell technologies market report. washington DC: Breakthrough Technologies Institute; 2014.

[6] Morikawa H, Kikuchi H, Saito N. Development and Advances of a V-Flow FC Stack for FCX Clarity. In: Honda R\&D Co. L, editor.: SAE International; 2009.

[7] Kim SC, Won JP, Park YS, Lim TW, Kim MS. Performance evaluation of a stack cooling system using $\mathrm{CO} 2$ air conditioner in fuel cell vehicles. International Journal of Refrigeration. 2009;32:70-7.

[8] Choi SUS, Eastman JA, . Enhancing Thermal Conductivity of fluids with Nanoparticles. ASME International Mechanical Engineering Congress \& Exposition. San Francisco, CA1995.

[9] Syam Sundar L, Sharma KV. An experimental study on heat transfer and friction factor of Al2O3 nanofluid. Journal of Mechanical Engineering and Sciences. 2011;1:99-112.

[10] Mahendran M, Lee GC, Sharma KV, Shahrani A. Performance of evacuated tube solar collector using water-based titanium oxide nanofluid. Journal of Mechanical Engineering and Sciences. 2012;3:301-10. 
[11] Hussein AM, Bakar RA, Kadirgama K, Sharma KV. Experimental measurements of nanofluids thermal properties. International Journal of Automotive and Mechanical Engineering. 2013;7:850-63.

[12] Ravisankar B, Tara Chand V. Influence of nanoparticle volume fraction, particle size and temperature on thermal conductivity and viscosity of nanofluids- A review. International Journal of Automotive and Mechanical Engineering. 2013;8:1316-38.

[13] Saidur R, Leong KY, Mohammad HA. A review on applications and challenges of nanofluids. Renewable and Sustainable Energy Reviews. 2011;15:1646-68.

[14] Wang Y, Chen KS, Mishler J, Cho SC, Adroher XC. A review of polymer electrolyte membrane fuel cells: Technology, applications, and needs on fundamental research. Applied Energy. 2011;88:981-1007.

[15] DOE-EERE DoE. Technical work-Fuel cell. Fuel cell Technology office; 2009.

[16] Maes J-P, Lievens S. Method for fuel cell coolant systems. US2007.

[17] Zakaria IA, Mustaffa MR, Mohamed WANW, Mamat AMI. Steady - State Potential Energy Recovery Modeling of an Open Cathode PEM Fuel Cell Vehicle. Applied mechanics and materials. 2014;465 - 466.

[18] Cengel G. Heat and Mass Transfer : Fundamentals and Application. 4th ed: Mc Graw hills companies; 2011.

[19] Hosseinzadeh E, Rokni M, Rabbani A, Mortensen HH. Thermal and water management of low temperature Proton Exchange Membrane Fuel Cell in fork-lift truck power system. Applied Energy. 2013;104:434-44.

[20] Hashmi SMH. Cooling Strategies for PEM FC Stacks. Universität der Bundeswehr Hamburg; 2010.

[21] Eaton ER, Boon WH, Smith CJ. Chemical base for fuel cell engine heat exchange coolant/antifreeze commprising 1'3_Propanediol. In: Patent US, editor. United States 2008.

[22] Mock J, McMullen P, Mohapatra S. Fuel Cell Coolant Optimization and scale up. Dynalene Inc; 2011.

[23] C.Mohapatra S. fuel cell and fuel cell coolant compositions. united state of america2006.

[24] McMullen P, Mohapatra S, Donovan E. Advances in PEM Fuel Cell Nano-Coolant. 2013.

[25] Peyghambarzadeh SM, Hashemabadi SH, Hoseini SM, Seifi Jamnani M. Experimental study of heat transfer enhancement using water/ethylene glycol based nanofluids as a new coolant for car radiators. International Communications in Heat and Mass Transfer. 2011;38:1283-90.

[26] Eastman JA, Choi SUS, Li S, Yu W, Thompson LJ. Anomalously increased effective thermal conductivities of ethylene glycol-based nanofluids containing copper nanoparticles. Appl Phys Lett. 2001;78:718-20.

[27] Murshed SMS, Leong KC, Yang C. Investigations of thermal conductivity and viscosity of nanofluids. International Journal of Thermal Sciences. 2008;47:560-8.

[28] Lee S, Choi SU-S, Li S, Eastman JA. Measuring Thermal Conductivity of Fluids Containing Oxide Nanoparticles. JOURNAL OF HEAT TRANSFER. 1999.

[29] Wang X, Xu X, Choi SUS. Thermal Conductivity of Nanoparticle-Fluid Mixture. Journal of Thermophysics And Heat Transfer. 1999;Vol. 13.

[30] Xie H, Wang J, Xi T, Liu Y, Ai F, Wu Q. Thermal conductivity enhancement of suspensions containing nanosized alumina particles. J Appl Phys. 2002;91:4568-72.

[31] Wang X-Q, Mujumdar AS. Heat transfer characteristics of nanofluids: a review. International Journal of Thermal Sciences. 2007;46:1-19.

[32] Kwak K, Kim C. Viscosity and thermal conductivity of copper oxide nanofluid dispersed in ethylene glycol. Korea-Australia Rheology Journal. 2005;Vol. 17 pp. 3540.

[33] Syam Sundar L, Venkata Ramana E, Singh MK, Sousa ACM. Thermal conductivity and viscosity of stabilized ethylene glycol and water mixture $\mathrm{Al} 2 \mathrm{O} 3$ nanofluids for heat 
transfer applications: An experimental study. International Communications in Heat and Mass Transfer. 2014;56:86-95.

[34] Dynalene. Dynalene FC. In: Inc D, editor.2013.

[35] Takashiba T, Yagawa S. Development of fuel cell coolant. Honda R\&D technical review: Honda R\&D C0.Ltd; 2009.

[36] Elhamid MHA, Mikhail YM, Blunk RH, Lisi DJ. Inexpensive dielectric coolant for fuel cell stacks. US2004.

[37] Ballard BPSI. FCgen®-1310 Fuel Cell Stack. 2012.

[38] Sundar LS, Shusmitha K, Singh MK, Sousa ACM. Electrical conductivity enhancement of nanodiamond-nickel (ND-Ni) nanocomposite based magnetic nanofluids. International Communications in Heat and Mass Transfer. 2014;57:1-7.

[39] McMullen P, Mohapatra S, Donovan E. Advances in PEM Fuel Cell Nano-Coolant. 2013.

[40] Wong KFV, Kurma T. Transport properties of alumina nanofluids. Nanotechnology. 2008;19.

[41] Ganguly S, Sikdar S, Basu S. Experimental investigation of the effective electrical conductivity of aluminum oxide nanofluids. Powder Technology. 2009;196:326-30.

[42] Baby TT, Ramaprabhu S. Investigation of thermal and electrical conductivity of graphene based nanofluids. J Appl Phys. 2010;108.

[43] Teng TP, Cheng CM, Pai FY. Preparation and characterization of carbon nanofluid by a plasma arc nanoparticles synthesis system. Nanoscale Research Letters. 2011;6:X1-11.

[44] Sikdar S, Basu S, Ganguly S. Investigation of electrical conductivity of titanium dioxide nanofluids. International Journal of Nanoparticles. 2011;4:336-49.

[45] Solanki JN, Murthy ZVP. Preparation of silver Nanofluids with High Electrical Conductivity. Journal of Dispersion Science and Technology. 2011;32:724-30.

[46] Konakanchi H, Vajjha R, Misra D, Das D. Electrical conductivity measurements of nanofluids and development of new correlations. Journal of Nanoscience and Nanotechnology. 2011;11:6788-95.

[47] Baby TT, Sundara R. Synthesis and transport properties of metal oxide decorated graphene dispersed nanofluids. Journal of Physical Chemistry C. 2011;115:8527-33.

[48] Shen LP, Wang H, Dong M, Ma ZC, Wang HB. Solvothermal synthesis and electrical conductivity model for the zinc oxide-insulated oil nanofluid. Physics Letters, Section A: General, Atomic and Solid State Physics. 2012;376:1053-7.

[49] Minea AA, Luciu RS. Investigations on electrical conductivity of stabilized water based Al2O3 nanofluids. Microfluidics and nanofluidics. 2012;13:977-85.

[50] Kole M, Dey TK. Investigation of thermal conductivity, viscosity, and electrical conductivity of graphene based nanofluids. J Appl Phys. 2013;113:124308

[51] Sarojini KGK, Manoj SV, Singh PK, Pradeep T, Das SK. Electrical conductivity of ceramic and metallic nanofluids. Colloids and Surfaces A: Physicochemical and Engineering Aspects. 2013;417:39-46.

[52] Maxwell JC. A Treatise on Electricity and Magnetism. Second edition ed. Cambridge, U.K.: Oxford University Press; 1904.

[53] Bruggeman DAG. Berechnung verschiedener physikalischer Konstanten von heterogenen Substanzen. I. Dielektrizitatskonstanten und Leitfahigkeiten der Mischkorper aus isotropen Substanzen. Ann Phys Leipzig. 1935;24:636-79.

[54] Yu L, Liu D. Study of the Thermal Effectiveness of Laminar Forced Convection of Nanofluids for Liquid Cooling Applications. Components, Packaging and Manufacturing Technology, IEEE Transactions on. 2013;PP:1-.

[55] VincentWong K-F, Kurma T. Transport properties of alumina nanofluids. Nanotechnology 2008;19.

[56] Baby TT, Ramaprabhu S. Investigation of thermal and electrical conductivity of graphene based nanofluids. Journal of Applied Physics. 2010;108. 
[57] Duangthongsuk W, Wongwises S. Measurement of temperature-dependent thermal conductivity and viscosity of TiO2-water nanofluids. Experimental Thermal and Fluid Science. 2009;33:706-14.

[58] Vajjha RS, Das DK. Experimental determination of thermal conductivity of three nanofluids and development of new correlations. International Journal of Heat and Mass Transfer. 2009;52:4675-82.

[59] Sharma P, Baek I-H, Cho T, Park S, Lee KB. Enhancement of thermal conductivity of ethylene glycol based silver nanofluids. Powder Technology. 2011;208:7-19.

[60] Chandrasekar M, Suresh S, Chandra Bose A. Experimental investigations and theoretical determination of thermal conductivity and viscosity of Al2O3/water nanofluid. Experimental Thermal and Fluid Science. 2010;34:210-6.

[61] Lee SW, Park SD, Kang S, Bang IC, Kim JH. Investigation of viscosity and thermal conductivity of $\mathrm{SiC}$ nanofluids for heat transfer applications. International Journal of Heat and Mass Transfer. 2011;54:433-8.

[62] Yiamsawasd T, Dalkilic AS, Wongwises S. Measurement of the thermal conductivity of titania and alumina nanofluids. Thermochimica Acta. 2012;545:48-56.

[63] Philip J, Shima PD. Thermal properties of nanofluids. Advances in Colloid and Interface Science. 2012;183-184:30-45.

[64] Mahbubul IM, Saidur R, Amalina MA. Latest developments on the viscosity of nanofluids. International Journal of Heat and Mass Transfer. 2012;55:874-85.

[65] Bin Razali MZ, Khiar MSA, Zakaria IA, Mohamed WANW. Effect of temperature towards electrical conductivities of low concentration of AL2O3 nanofluid in electrically active cooling system. Control System, Computing and Engineering (ICCSCE), 2014 IEEE International Conference on2014. p. 444-8.

[66] Zakaria I, Azmi WH, Mohamed WANW, Mamat R, Najafi G. Experimental Investigation of Thermal Conductivity and Electrical Conductivity of Al2O3 Nanofluid in Water - Ethylene Glycol Mixture for Proton Exchange Membrane Fuel Cell Application. International Communications in Heat and Mass Transfer. 2015;61:61-8.

[67] Zakaria IA, Michael Z, Ihsan Mamat AM, Najmi Wan Mohamed WA. Thermal and electrical experimental characterization of Ethylene Glycol and water mixture nanofluids for a 400w Proton Exchange Membrane Fuel Cell. Control System, Computing and Engineering (ICCSCE), 2014 IEEE International Conference on2014. p. 641-6.

[68] Ramos-Alvarado B, Li P, Liu H, Hernandez-Guerrero A. CFD study of liquid-cooled heat sinks with microchannel flow field configurations for electronics, fuel cells, and concentrated solar cells. Applied Thermal Engineering. 2011;31:2494-507.

[69] Pandiyan S, Jayakumar K, Rajalakshmi N, Dhathathreyan KS. Thermal and electrical energy management in a PEMFC stack - An analytical approach. International Journal of Heat and Mass Transfer. 2008;51:469-73.

[70] Kandlikar SG, Lu Z. Thermal management issues in a PEMFC stack - A brief review of current status. Applied Thermal Engineering. 2009;29:1276-80.

[71] Sohel MR, Khaleduzzaman SS, Saidur R, Hepbasli A, Sabri MFM, Mahbubul IM. An experimental investigation of heat transfer enhancement of a minichannel heat sink using A12O3- $\mathrm{H} 2 \mathrm{O}$ nanofluid. International Journal of Heat and Mass Transfer. 2014;74:164-72.

[72] Khaleduzzaman SS, Saidur R, Selvaraj J, Mahbubul IM, Sohel MR, Shahrul IM. Nanofluids for Thermal Performance Improvement in Cooling of Electronic Device Advanced Materials Research. 2014;832.

[73] Naphon P, Nakharintr L. Heat transfer of nanofluids in the mini-rectangular fin heat sinks. International Communications in Heat and Mass Transfer. 2013;40:25-31.

[74] Keshavarz Moraveji M, Mohammadi Ardehali R, Ijam A. CFD investigation of nanofluid effects (cooling performance and pressure drop) in mini-channel heat sink. International Communications in Heat and Mass Transfer. 2013;40:58-66. 

coolant

[75] Prasher R, Song D, Wang J, Phelan P. Measurements of nanofluid viscosity and its implications for thermal applications. Appl Phys Lett. 2006;89:133108.

[76] Garg J, Poudel B, Chiesa M, Gordon JB, Ma JJ, Wang JB, et al. Enhanced thermal conductivity and viscosity of copper nanoparticles in ethylene glycol nanofluid. J Appl Phys. 2008;103:074301.

[77] Azmi WH, Sharma KV, Sarma PK, Mamat R, Anuar S. Comparison of convective heat transfer coefficient and friction factor of $\mathrm{TiO}_{2}$ nanofluid flow in a tube with twisted tape inserts. International Journal of Thermal Sciences. 2014;81:84-93. 